\title{
EFFECT OF N, K, CI ON PHOTOSYNTHESIS AND WATER RELATIONS OF OPEN POLLINATED TALL (typica) COCONUT SEEDLINGS
}

\author{
C. JAYASEKARA, R. G. MUDALIGE, and C. S. RANASINGHE \\ Coconut Research Institute of Sri Lanka.
}

ABSTRACT

$\mathrm{CO}_{2}$ assimilation and plant water status were measured in sand-culture-grown amputated coconut seedlings treated with three levels of $\mathrm{N}, \mathrm{K}$, and $\mathrm{C} 1$ and subjected to different soil water deficit conditions. Application of increased levels of $\mathrm{N}$ and $\mathrm{K}$ enhanced the assimilation of $\mathrm{CO}_{2}$ while individual and combined effects of $\mathrm{N}, \mathrm{K}$, and $\mathrm{Cl}$ improved the water economy of coconut seedlings. Under the soil water deficit conditions, adequate supply of $\mathrm{N}$ helped to maintain high leaf water potential by the accumulation of solutes like proline and sugars. Whereas, adequate supply of $\mathrm{K}$ and $\mathrm{Cl}$ themselves acted as osmotica by increased accumulation of these nutrients in leaf tissues, although other solute concentrations such as those of sugars and proline were reduced. Our data show that maintenance of sufficient levels of $\mathrm{N}$ and $\mathrm{K}$ contribute to the growth of the coconut seedling through improved gaseous exchange, $\mathrm{CO}_{2}$ assimilation and better partitioning of assimilated carbon into shoot and roots. potassium and $\mathrm{Cl}$ are further important for maintenance of water status of coconut seedlings by improved stomatal regulation, water uptake and osmotic adjustment of tissues under water deficit conditions.

\section{INTRODUCTION}

Productivity of perennial tree crops mainly depends on climatic factors, availability of soil nutrients and fertilizer usage in addition to their genotypic characters. Nitrogen is an important nutrient for coconut, specially during the seedling stage. It is essential because if combines with organic molecules to form biologically active compounds like amino acids, proteins, nucleic acids, phyto hormones etc. Nitrogen deficiency in coconut palms manifests itself by yellowing of leaves, reduced vegetative growth, diminished female flower production and yield.

It has been reported that potassium and magnesium are the two most limiting nutrients affecting the productivity of coconut palms in Sri Lanka with about $80 \%$ of the coconut plantations showing low leaf nutrient levels (Jayasekara, 1989). Potassium ion is found to be the only ion which has a major effect on the diffusion of $\mathrm{CO}^{2}$ to the chloroplast in mesophyll cells. Peaslee and Moss (1968) and Terry and Ulrich (1973) reported that decline in rate of photosynthesis of maize and sugar beet leaves as potassium become deficient. Potassium further influences protein synthesis (Hsiao et al., 1970), water uptake by roots (Mangel and Kirkby, 1980), cell turgor maintenance (Leigh and Wyne Jones, 1984), water transport and enzymatic reactions. Potassium in coconut is mainly stored in the husks, nut water, leaves and petioles. The average annual removals of potassium from those crop components were found to be approximately 0.75 to 0.9 kg palm ${ }^{-1} y^{-1}$ (Nathaniel, 1969). 
Until recently, the importance of chlorine as a plant nutrient in coconut was not known. However, recent studies have shown that chloride ions are essential for certain genera of plants including palmae (Von Uexkull, 1984). Potassium and chloride ions in plant cells do not complex with organic molecules but function as free ions. Potassium in plant cell exists compartmentalized as cytoplasmic and vacuolar $K^{+}$. These subcellular compartments have different $\mathrm{K}^{+}$concentrations (Leigh and Wyne Jones, 1986). Cytoplasmic potassium is essential for biochemical processes such as photosynthesis, glycolysis, starch and protein synthesis, whereas vacuolar potassium mainly act as an osmoticum. Stomatal regulation for gaseous exchange and transpiration depend on the turgor and solute potential of guard cells.

In this paper importance of $\mathrm{N}, \mathrm{K}$, and $\mathrm{Cl}$ for two main physiological processes namely (a) $\mathrm{CO}_{2}$ assimilation and (b) water relations of the coconut seedlings are discussed. The processes of transpiration (E) and of $\mathrm{CO}_{2}$ assimilation (A) both are crucial in plant productivity and depend on $\mathrm{CO}_{2}$ and water vapour diffusion through stomata. Stomatal regulation of gaseous exchange takes place by opening and closing of stomatal aperture, which is stimulated by turger mediated process within guard cells and potassium play a key role as the osmotic agent for turgor changes. Variation in stomatal aperture in relation to the rate of transpiration or $\mathrm{CO}_{2}$ assimilation are quantified at the leaf or whole plant level as changes in either stomatal diffusive resistance $(\mathrm{g})$ or conductance (Reciprocal of $\mathrm{g}$ ). Measure of these parameters in the field or glass house level could be used as an indicator of either water status, photosynthesis or transpiration rates of plants. Similarly water status of plants could be measured as water content (WC), relative water content (RWC), and water potential $(\psi)$ of tissues. Eventhough, WC and RWC quantify the amount of water present in a plant tissues they do not imply the driving force for water within tissues. In simple terms water potential $(\psi)$ is the driving force for water movement in liquid phase within the soil-plant system. Presently pressure chamber and psychrometers are widely used to meassure plant and soil water potentials. In this study pressure chamber has been used to measure leaf water potential of coconut leaves.

\section{MATERIAL AND METHODS}

\section{Material :}

Open pollinated typica coconut seednuts were obtained from the Bandirippuwa estate, Lunuwila and seedlings were grown from dehusked seednuts in nursery beds. Plastic containers (30 $\mathrm{cm}$ in diameter and $34 \mathrm{~cm}$ in height) were filled with washed sand. Seedlings were amputated from the seednuts, eight weeks after sprouting. Any damaged roots were cut and dipped in a 5\% benlate solution (fungicide) for 10 minutes. Cut ends were covered with a panel dressing Tb - 192 (CIC Ltd) and seedlings were transferred into the containers of washed sand.

\section{Experimental :}

Experiment was a $3^{4}$ factorial confounded block design with nine blocks and each block with nine replicates. Three levels each of $\mathrm{N}, \mathrm{K}$, and $\mathrm{Cl}$ as $0 \mathrm{mM}, 5 \mathrm{mM}$, and $10 \mathrm{mM}$ were used as the nutrient treatments. Half strength Hoagland solution was used to supply other macro and micro nutrients. In $0 \mathrm{mM} \mathrm{N}, \mathrm{K}$, and $\mathrm{Cl}$ treatments ionic strength of the Hoagland solution was balanced by substitution of $\mathrm{Na}$ and $\mathrm{SO}_{4}$ ions. Nutrients were applied three times a week and seedlings were watered to the field capacity with deionized water for ten months. Two drying cycles were imposed to simulate drought conditions. One set of seedlings was dried up to six weeks and the other set was dried for eight weeks by witholding application of water. A third set was maintained at the 
field capacity by regular watering throughout the study. At the end of each drying cycle, seedlings were rewatered up to the field capacity. Whenever necessary few leaflets were harvested from last fully expanded leaf for $\psi_{1}$, chlorophyll. and amino acid and sugar assay.

\section{METHODS}

\section{Chlorophyll concentration :}

Chlorophyll in fresh leaf samples was extracted homogenizing in $20 \mathrm{ml}$ of $80 \%$ acetone $(\mathrm{v} / \mathrm{v})$ in an ultra turrex. After centrifugation $(1500 \mathrm{rpm}, 5 \mathrm{~min})$ at room temperature, absorbance of the supernatant fraction was measured at 645 and $668 \mathrm{~nm}$ in a UV/VIS spectrophotometer (Shimadzu UV 160- A, Japan).

$\mathrm{CO}_{2}$ assimilation :

The rate of $\mathrm{CO}_{2}$ assimilation under planthouse conditions was measured using a portable ADC photosynthesis meter (Analytical Development Co. Ltd., Hertfordshire, U.K.). The instrument was operated in the differential mode at the normal environmental conditions.

\section{Leaf water potential and stomatal diffusive resistance :}

Water potential of leaves was measured using a commercial type pressure chamber (Soil Moisture Corporation, California, U.S.A.). Stomatal diffusive resistance and rate of transpiration of leaves were measured using a Li-1600 steady state porometer (LI-COR INC., Nebraska, USA)

\section{Sugars and proline :}

Dried ground leaf samples $(0.5 \mathrm{~g})$ were homogenized in an ultra turrex with $20 \mathrm{ml}$ of $80 \%$ ethanol $(v / v)$ and with the use of chloroform-water, chlorophyll was separated from the aqueous fraction. Aqueous fractions were then centrifuged $(1500 \mathrm{rpm}, 5 \mathrm{~min})$ and supernatant fractions were then centrifuged $(1500 \mathrm{rpm}, 5 \mathrm{~min}$ ) and supernatant fractions were concentrated to a constant volume of $5 \mathrm{ml}$. Total sugars in the concentrated fractions were determined by the phenolsulphuric assay method (Dubois et al., 1956).

Reducing sugars in the aqueous fractions were determined by the 3-5 dinitrosalicylic acid method as described by Sumner (1924).

Fresh leaf samples $(5 \mathrm{~g})$ were homogenized with $80 \%$ ethanol in an ultra turrex and the soluable fractions were extracted as described above and proline concentration was determined by the method of Troll and Lindsay (1955) without using permutit-T resin.

\section{RESULTS}

\section{Effect of $\mathbf{N}, \mathbf{K}$, and $\mathrm{Cl}$ on Chlorophyll content:}

The effects of different treatment levels of $\mathrm{N}, \mathrm{K}$, and $\mathrm{Cl}$ on leaf chlorophyll concentration as well as the chlorophyll $\mathrm{a} / \mathrm{b}$ ratio are given in the Table 1 . Analysis of leaf nutrients revealed that $\mathrm{N}, \mathrm{K}$, and $\mathrm{Cl}$ exceeded the critical levels when the treatment nutrient levels were increased from $5 \mathrm{mM}$ to $10 \mathrm{mM}$. High $\mathrm{N}$ levels increased the chlorophyll a \& b concentrations. Nevertheless, chlorophyll $\mathrm{a} / \mathrm{b}$ ratio was decreased significantly. Potassium has no effect on leaf chlorophyll 
concentration. Increased levels of chlorine reduced the chlorophyll concentration possibly by reducing synthesis.

\section{The effect on $\mathrm{CO}_{2}$ assismilation and assimilate partitioning :}

$\mathrm{CO}_{2}$ assimilation, stomatal conductance and inter cellular $\mathrm{CO}_{2}$ concentration of the second expanded leaf of the individual seedlings were determined at field capacity when the seedlings were 8,9, and 10 months old. Fig. 1 shows the relationship between rate of photosynthesis and transpiration of coconut seedling at field capacity and with different levels of $\mathrm{N}, \mathrm{K}$, and $\mathrm{Cl}$ for averaged data for three consecutive measurements. Increased supply of $\mathrm{N}$ and $\mathrm{K}$ enhanced the rate of $\mathrm{CO}_{2}$ assimilation, whereas chlorine showed a negative response by reducing assimilation of $\mathrm{CO}_{2}$. Increased supply of $\mathrm{K}$ and reduced supply of $\mathrm{Cl}$ increased the leaf water potential (less negative) of seedlings with concomitant increase in the rate of $\mathrm{CO}_{2}$ assimilation. Increased supply of $\mathrm{N}$ increased the assimilation of $\mathrm{CO}_{2}$ of leaves but reduced the leaf water potential of coconut seedlings.

\section{The effect on water relations :}

Leaf water potential $\left(\Psi_{2}\right)$, rate of transpiration (E), and stomatal diffusive resistance $(\mathrm{g})$ of the same leaves used for $\mathrm{CO}_{2}$ assimilation studies were measured concurrently. Fig. 2 shows the relationship between $\psi_{1}$ and $\mathrm{E}$ with different levels of $\mathrm{N}, \mathrm{K}$, and $\mathrm{Cl}$. Nitrogen and $\mathrm{K}$ have shown linear and contrasting effects on leaf water potential, whereas transpiration was increased with increase in the supply on $\mathrm{N}$ and $\mathrm{K}$. Tables 2, 3, and 4 describe the effect of interaction between of $\mathrm{K}$ and $\mathrm{Cl}, \mathrm{N}$ and $\mathrm{Cl}$, and $\mathrm{N}$ and $\mathrm{K}$ on leaf water pqtential, transpiration, and stomatal diffusive resistance of seedlings. All three nutrient combinations displayed significent interactive effects either enhancing or decreasing their response to these parameters depending on the levels of nutrients.

\section{The effect of N,K, and Cl on osmotic adjustment :}

Some plants have the ability to maintain tissue turgor at higher levels under soil water deficit conditions by accumulation of solutes within the tissues. Sugars, sugar acids, cations and anions like $\mathrm{k}, \mathrm{Na}, \mathrm{Cl}$, malate, imino acids like proline and glycinebetaine are some such substances accumulated within tissues to maintain turgor balance. Table 5 shows the accumulated levels of sugars, proline, $\mathrm{K}$, and $\mathrm{Cl}$ under water deficit conditions. It was very clear that in the presence of adequate supply of $\mathrm{N}$, leaf sugar and proline concentrations were increased at soil water deficit conditions, whereas in the presence of adequate supply of $\mathrm{K}$ and $\mathrm{Cl}$, proline concentration was decreased but concentrations of these ions themselves were increased in leaves. These results suggest that $\mathrm{K}$ and $\mathrm{Cl}$ help to maintain turgor balance under water deficit conditions.

\section{DISCUSSION}

Nitrogen is an important nutrient for plant growth. As in many other plants $\mathrm{N}$ has increased chlorophyll content and photosynthetic activity of coconut seedlings. Nitrogen deficiency results in reduction of stomatal conductance (Balton and Brown, 1980) or mesophyll conductance (Wong, 1979) or both (Navin and Loomis, 1970; Brown and Wilson, 1983). Jayasekara (1986) reported that the reduction in leaf water potential, stomatal conductance, and photosynthetic activity under nitrogen deficiency and water deficit conditions in Chamaedorea elegans palms. Similarly nitrogen deficiency reduces the stomatal conductance and photosynthetic activity in coconut seedlings. Nitrogen metabolism is inhibited under reduced water potentials. Synthesis of 


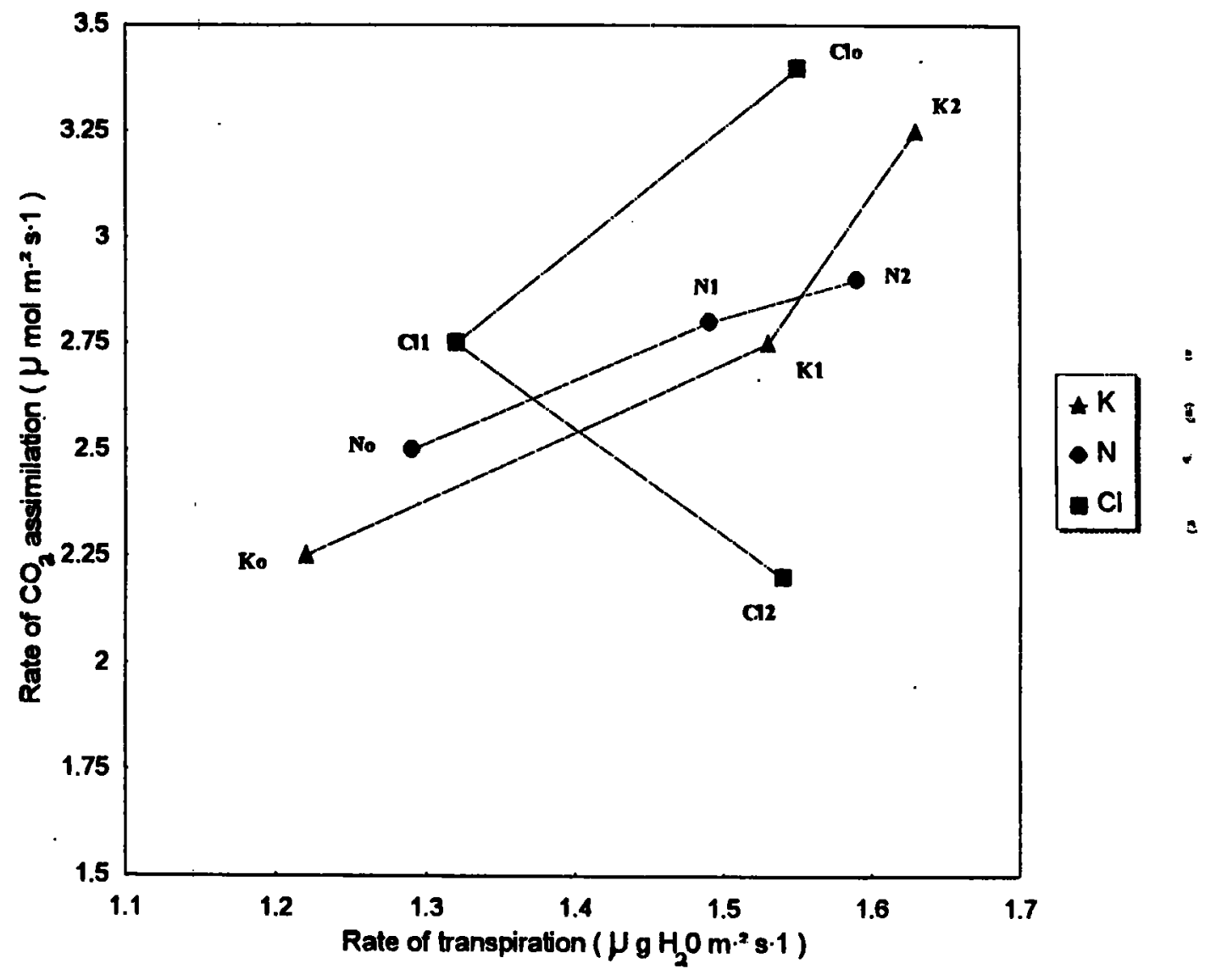

Figure 1: Relationship between rates of transpirations and rate of photosynthesis with different treatment levels of $N(\bullet), K(\hookrightarrow)$ and $\mathrm{Cl}(\bullet)$. 


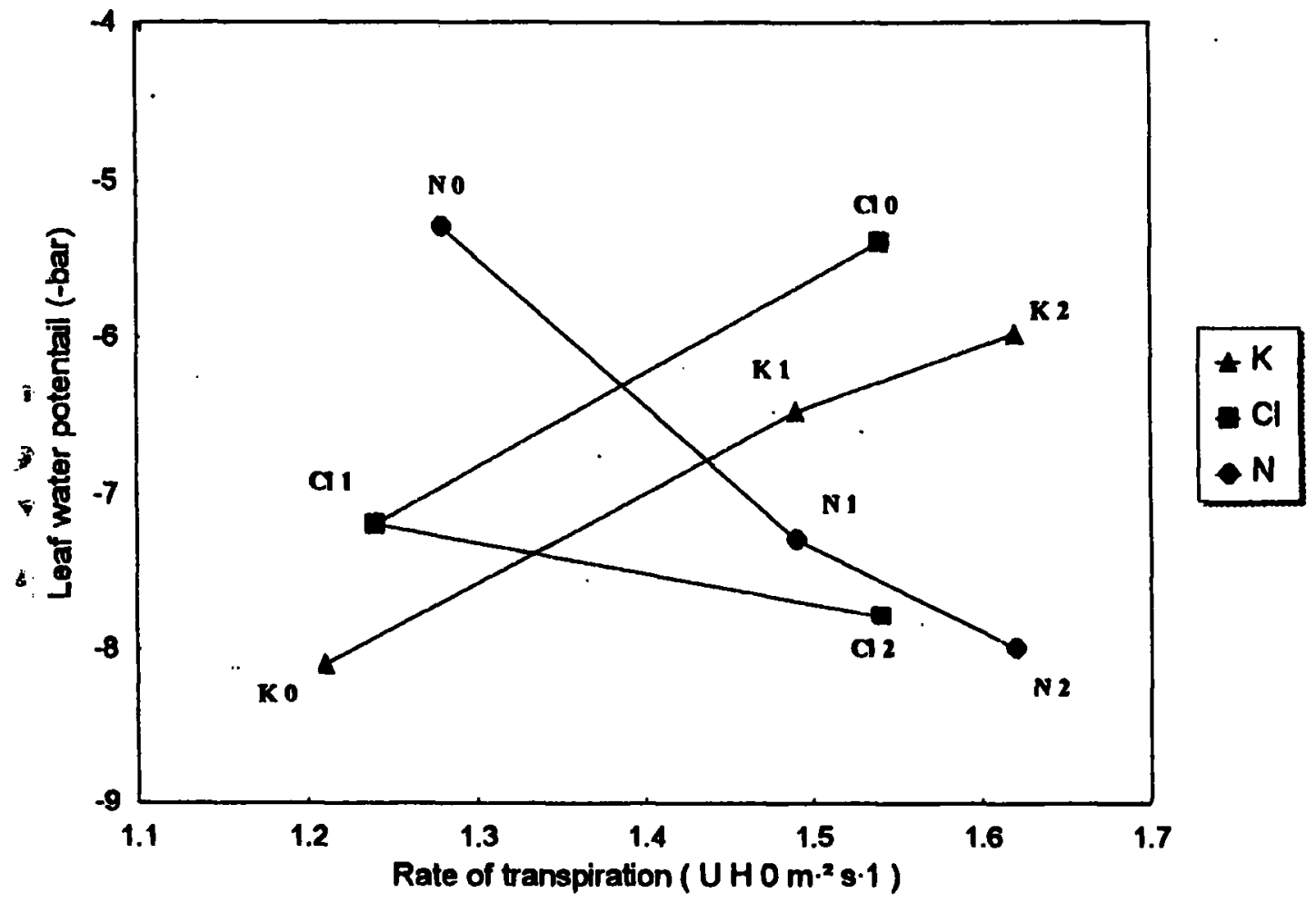

Figure 2: Relationship between rate of transpiration and leaf water potential with different treatment levels of $\mathrm{N}(\bullet), \mathrm{K}(\leftrightarrow)$, and $\mathrm{Cl}(\bullet)$. 


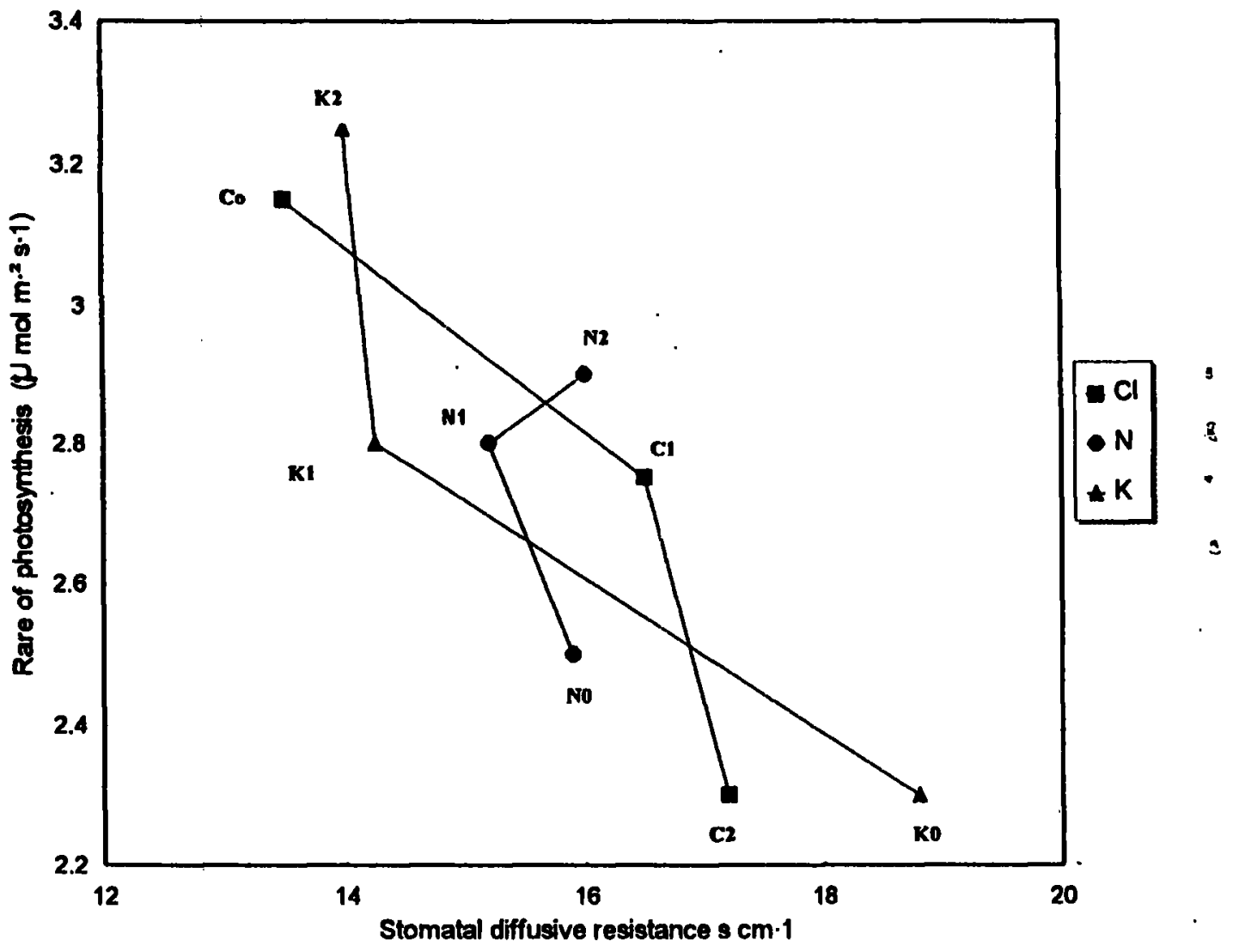

Figure 3: Relationship between rate of photosynthesis and stomatal diffusive resistance under different levels of $N(\bullet), K(\hookrightarrow)$, and $\mathrm{Cl}(\bullet)$. 
proteins inhibited and hydrolysis of existing proteins is enhanced, consequently increasing the concentration of free amino acids or orther nitrogen compounds. This is specially so in the case of the imino acid proline. In this study it became apparent that under water deficit conditions, total leaf amino acids and proline concentrations were increased with increase in the nitrogen supply.

Gaseous exchange of water vapour and $\mathrm{CO}_{2}$ in leaves largely depend on the movement stomatal guard cells. During the opening and closure of stomata, $\mathrm{K}$ plays a pivotal role as an osmotic agent for turgor changes in the guard cells. Humble and Raschke (1971) provided convincing evidence for the requirement of $\mathrm{K}^{+}$for stomatal movement by electrone probe analysis. Very recently by the same method, Serge Braconnier and Jean d'Auzac (1990) reported, that on stomatal opening, increase of $\mathrm{K}^{+}$and $\mathrm{Cl}^{-}$in guard cells of coconut and oil palm leaves and their concentration variation percentage of $\mathrm{K}^{+}$and $\mathrm{Cl}^{-}$were quite similar for both species of palms. In general stomata open less under K-deficiency, but this may occur only at an advanced stage of deficiency in many plants (Hsiao, 1975). As presented in Fig. 3, higher levels of $\mathrm{K}$ showed a marked increase in assimilation of $\mathrm{CO}_{2}$ probably through increased stomatal conductance for gaseous exchange and maintenance of high water potential within leaves. Further, requirement of $\mathrm{K}$ for the photophosphorylation process within chloroplasts (Trebst, 1980) and promotion of RuBp-carboxylase enzyme synthesis (Peoples and Koch, 1979) has been reported for other plants. However, such effects were not investigated as they were beyond the scope of this study. Uptake of $\mathrm{K}^{+}$by root cells depresses the osmotic potential of the cells, thereby inducing uptake of water from soil. Water transport into the xylem vessels is also an osmotic process, function of $\mathrm{K}^{+}$in which is very important for upward movement of water. Therefore, $K^{+}$is the important osmoticum which drives water flux from the surrounding cells into the xylem vessels (Baker and Weatherly, 1969). In this study it was observed that $\mathrm{K}$ and $\mathrm{Cl}$ accumulated in leaf tissues have possibly acted as osmotica to maintain the turgor balance under water deficit conditions. In the treatments where high concentration of potassium, high transpiration rates and $\psi_{1}$ were maintained. Thus from these observations it was clear that $\mathrm{K}$ in coconut seedlings has helped to regulate turgor potential within tissues, maintain water balance or water economy by influencing water uptake, upward movement and transpiration through stomata. At the same time $\mathrm{K}^{+}$helps to maintain high photosynthetic activity in coconut seedlings. These beneficial effects of $\mathrm{K}$ in coconut seedlings are particularly important for crop production if they hold also for native palms.

Chlorine deficiency in coconut leaves manifests itself by drying of leaves at the base as a result of inadequate supply of water (Ollagnier, 1985). Several authors have reported that the beneficial effects of $\mathrm{Cl}$ on yield, drought tolerance induced by $\mathrm{K}$ and $\mathrm{Cl}$, and improvement of assimilation of $\mathrm{CO}_{2}$ (Magat et al., 1975; Von Uexkull, 1984; Ollagnier, 1985). Increased yield and growth of coconut and oil palm were observed when leaf $\mathrm{Cl}$ concentration was brought up to the critical levels of $0.65 \%$ of dry weight. However, in this study we found that $\mathrm{Cl}$ concentration in the zero chlorine treatments was in the range of $0.40-0.90 \%$ depending on the $\mathrm{N}, \mathrm{K}$, and water treatments.

High concentrations of chlorine in the zero treatments probably resulted from the tissue $\mathrm{Cl}$ levels at the time of amputation of seedlings and also from $\mathrm{Cl}$ received from the atmosphere (wind borne from the coast). Therefore, the effect of low levels of $\mathrm{Cl}$ supply (below critical level) on physiological processes of coconut palm seedlings was not well reflected in this study. High tissue $\mathrm{Cl}$ concentrations (above criticial level) resulted in undesirable effects on growth of coconut seedling by reducing chlorophyll content and assimilation of $\mathrm{CO}_{2}$. However, interactive effects of $\mathrm{K}$ and $\mathrm{Cl}$ gave beneficial effects by improving osmotic adjustment by turgor balance and leaf water potential under water-limiting conditions. 


\section{ACKNOWLEDGEMENTS}

The authors wish to thank Mr. D. T. Mathes, Head/Biometry Division for statistical designing the experiments and for the analysis of data and also Miss P. S. A. de Saram and Mr. R. D. N. Premasiri, Technical Assistant for their help in the experimental work.

These experiments were carried out under the project awarded to C. J. by Canadian International Development Agency (CIDA). Assistance of CIDA and Natural Resources Energy and Science Authority of Sri Lanka (NARESA) is greatfully acknowledged.

\section{REFERENCES}

Baker D. A. and Weatherly P. E. (1969) Water and solute transport by exuding root system of Ricinus cummunis. J Exp. Bot., 20, 485-95.

Bolton, J. K. and Brown, R. H. (1980) Photosynthesis of grass species differing in carbon dioxide fixation pathways. V. Responses of Panicum-maximum, Panicum mitiodse and tall fescue to nitrogen nutrition. Plant Physiol., 66: 97 - 100.

Braconnier, $S$ and Jean d'Auzec (1990) Chloride and stomtal conductance of coconut. Plant Physiol. Biochem., 28 (1) : 105 - 111.

Brown, R. H. and Wilson, J.R. (1983) Nitrogen response of panicum species differing $\mathrm{CO}_{2}$ fixation pathways. $\Pi \mathrm{CO}_{2}$ exchange characteristics. Crop Sci., 23 : 1154 - 1159.

Dubois, M, Gilles, K. A. Hamilton, J. K. Rebers, P. A., and Smith, F (1956) Colorimetric method for determination of sugars and related substances. Anal. Chem., 28 (3) : 350 - 356.

Hasiao, T C, Hagemen R H and E H Tyner (1970) Effects of potassium nutrition on protein and total free amino acids in Zea Mays. Crop Sci., 10 : 78 - 82.

Hsiao, T C (1975) Variables affecting stomatal opening - complicating effects. In : Measurements of stomatal apearture and diffusive resistance. E T Kenamasu Ed. Washington Statc Univ. Bull., 809 : 28 - 31 .

Humble, GD and Raschke, K (1971) Stomatal opening quantitively related to potassium transport. Evidence from electron probe analysis. Plant Phyiol., 48, 447 - 53.

Jayasekara, C (1986) Ecophysiological studies in relation to photosynthesis and assimilate partitioning in two species of palms - Ph D Thesis, Uni. of QLD. 96 - 104.

Jayasekara, K S (1989) Report of the Soils and Plant Nutrition Division - Annual Report of the Coconut Research Institute of Sri Lanka for 1989, 88 - 118.

Leigh, R A and Wyn Jones, R G (1986) Cellular compartmentation in plant nutrition : the selective cytoplasm and promiscuous vacuole. In Advances in Plant Nutrition Vol 2 (B Tinker and A Lauchli Ed) pp 249 - 279, Praeger, New York. 
Magat, S S, Margate, R Z and R L Prundente (1975) Yield improvement of coconut in elevated inland area of Davao by $\mathrm{KCl}$ fertilization. Oleagineux : 413-448.

Mangel, K and Kirkby, E A (1980) Potassium in crop production. Academic Press. 59 - 110.

Nathaniel, W R N (1969) The application of fertilizers to adult coconut palms in relation to theoretical concepts. fertilite., $35(11 / 12): 11-17$.

Navin, D J and Loomis, R S (1970) Nitrogen nutrition and photosynthesis in sugar-beat (Beta ulgaris L.) Crop Sci., $10: 21$ - 25.

Peaslee, D E and Moss D N (1968) Photosynthesis in K and Mg deficient (Zea mays L) leaves. Soil. Sci. Soc. Amer. Proc., 30 (2) : 220 - 223.

Peoples T R and Koch D W (1929) Role of potassium in carbon dioxide assimilation in Medicago sativa L. Plant Physiol., 63: 878 - 881.

Sumner, J B (1924) The estimation of sugar in diabetic urine, using dinitrosalicylic acid. J. Biol. Chem., 62: $287-290$.

Terry, N and Ultrich A (1973) Effects of potassium deficiency on the photosynthesis and respiration of leaves of sugar beet under conditions of low sodium supply. Plant physiol., 51: $1099-1101$.

Trebst, A (1980) Inhibitation in electron flow: Tools for the functional and structural localization of carriers and energy conserving sites. In: San Pietro A (Ed) Methods in enzymology Vol 69. Academic Press, London New York, pp 675 - 715.

Troll, W and Lindsley, J (1955) A photometric method for the determination of proline. J Biol. Chem., 215: 655 - 660 .

Von Uexkull, H R (1984) Chlorine in the nutrition of palm trees. ICOSANP, Kuala Lumpur 13 - 15 Aug 1989.

Wong, $\mathrm{S} \mathrm{C}$ (1979) Elevated atmospheric partial pressure of $\mathrm{CO}_{2}$ and plant growth. Interactions of nitrogen inhibition and photosynthesis capacity in $\mathrm{C}_{3}$ and $\mathrm{C}_{4}$ and plants. Oecologia, 44: 68 - 74. 